\title{
The Ross procedure is alive and well in Lübeck, Germany
}

\author{
Tirone E. David, MD
}

\author{
From the Division of Cardiovascular Surgery, Toronto General Hospital and the University of Toronto, Toronto, \\ Ontario, Canada. \\ Disclosures: Author has nothing to disclose with regard to commercial support. \\ Received for publication March 26, 2018; accepted for publication March 29, 2018; available ahead of print April \\ $21,2018$. \\ Address for reprints: Tirone E. David, MD, 200 Elizabeth St, 4N453, Toronto, Ontario M5G 2C4, Canada (E-mail: \\ tirone.david@uhn.ca). \\ J Thorac Cardiovasc Surg 2018;156:77-8 \\ $0022-5223 / \$ 36.00$ \\ Copyright (C) 2018 by The American Association for Thoracic Surgery \\ https://doi.org/10.1016/j.jtcvs.2018.03.128
}

There is an ever-increasing number of reports on late outcomes of the Ross procedure and Sievers and colleagues ${ }^{1}$ from Lübeck, Germany, have added one in this issue of the Journal. They describe the longitudinal results of a large cohort of patients followed up prospectively for a median of 12.5 years and propose a new method to quantify the quality of outcomes, a valve performance classification.

The series of Ross procedures of Sievers and colleagues ${ }^{1}$ contains 630 patients with a mean age of 44.7 years. Sievers and colleagues ${ }^{1}$ admit being selective in offering this operation to patients, and their patients are relatively healthy. This is a sensible approach, given the complexity of this type of aortic valve replacement. Unique in this series is the fact that all patients had the pulmonary autograft secured inside the aortic root in the subcoronary position or as an aortic root inclusion. The overall results were excellent. Patient survival was identical to that of the general population of Germany, although they did use the KaplanMeier method, and patients who had reoperation may have been excluded from the calculation. Twenty years after surgery, $86 \%$ of patients were free from Ross-related reoperation; $90 \%$ for the pulmonary autograft and $91 \%$ for the pulmonary homograft. I have been doing this operation for 3 decades, and I cannot provide better results than these. I doubt that anyone can. Interestingly, Sievers and colleagues ${ }^{1}$ could not identify any variable associated with increased risk of reoperation, not even preoperative aortic insufficiency. Figure E1 in their article shows very compelling curves of freedom from aortic insufficiency over time in favor of patients with preoperative aortic stenosis, although apparently the differences did not reach statistical significance.

A recent report by Skillington's group from Melbourne, Australia, on a series of 129 patients with bicuspid aortic valve and pure aortic insufficiency showed freedoms from reoperation on the aortic valve of $89 \%$ at 10 years and $85 \%$ at 20 years, with 10 patients at risk at 20 years. $^{2}$

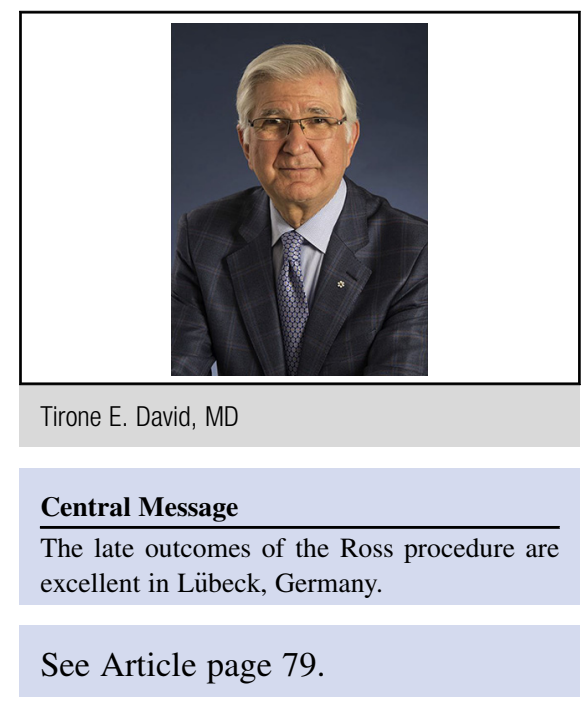

Skillington uses a modification of the aortic root inclusion technique to perform the Ross operation, making the native aortic root an external support to the pulmonary autograft. On the basis of Sievers' and Skillington's experiences, the Ross procedure should not be denied to patients with incompetent bicuspid aortic valves and dilated aortic annulus, as I have done for many years. ${ }^{3}$ They believe that the techniques of subcoronary implantation or aortic root inclusion play an important role in the late results.

In addition to providing the readers of the Journal with these very optimistic outcomes of the Ross procedure, Sievers and colleagues ${ }^{1}$ have proposed a new method of valve performance classification, whereby they combine the hemodynamic data obtained by echocardiography with symptoms and with current heart valve guidelines for intervention on the pulmonary autograft and homograft. They propose 5 classes: class $\mathrm{I}$ is when everything is normal, class $\mathrm{V}$ is when reoperation was done, and the classes in between indicate various degrees of valve dysfunction and possibly symptoms. I did not understand the purpose of including the degree of stenosis of the pulmonary autograft in the classification, because I have never seen one become stenotic, but I imagine that it is possible if the patient lives long enough. This new classification may prove to be a more difficult sell than Sievers' outstanding clinical results with the Ross procedure, which is alive and well in Lübeck, Germany.

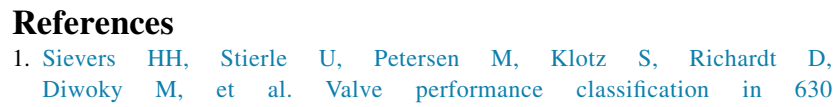


subcoronary Ross patients over 22 years. J Thorac Cardiovasc Surg. 2018:156:79-86.

2. Poha CL, Buratto E, Larobina M, Wynne R, O'Keefe M, Goldblatt J, et al. The Ross procedure in adults presenting with bicuspid aortic valve and pure aortic regurgitation: $85 \%$ freedom from reoperation at 20 years. Eur J Cardiothorac Surg. 2018;156:79-86.

3. David TE, David C, Woo A, Manlhiot C. The Ross procedure: outcomes at 20 years. J Thorac Cardiovasc Surg. 2014;147:85-93. 